\title{
Local Mass Media's Attitudes towards Environmental Situations in the East
}

\author{
SONGYOT BUAPHAUEN \\ Committee and Secretary of Innovative Political Communication, Program Department of Communication Arts \\ Faculty of Humanities and Social Sciences, Burapha University, Thailand \\ email: songyot_b@yahoo.com
}

\begin{abstract}
The research aims to study the local mass media's attitudes toward an environmental situation in the East of Thailand. A Qualitative study with in-depth interviews with key informants who are mass media in the eastern part of Thailand is applied. The informants are asked about their attitudes towards environmental problems in the East. The results are shown in 4 issues as follows: 1 . Illegal waste disposal is distributed into waste disposal in other people's properties and waste disposal into canals, 2. Coastal erosion in Laem Chabang area which is distributed into land loss and potential catch loss, 3. People's opposition to the town plan amendment which is distributed into the opposition of government's town plan development and the opposition of the town plan development benefitting the investors, 4 . The freshwater conflicts which are distributed into freshwater conflicts between agriculture and industrial sectors and the invasion of the industrial sector into the agricultural area.
\end{abstract}

Keyword: Local mass media, Environment, East Thailand

\section{Introduction}

Mass media reported news events and expressed its views to the public, and this linked people to their government, and at the same time transfer messages from the people to public institutes. Mass media are eligible to present the "messages" the ones believed to be useful for the people in the forms of news, articles, editorials, or political cartoon strips. Mass media can offer knowledge to the public by expressing their views in the news articles and critics. Also, the media can present opinions on how particular events affect people's way of life and to acknowledge the government of how the public feels toward any policies or projects (Buaphuean, 2006)

Local media were responsible for reporting news and health knowledge to the local people. This is the role of the media to build up health awareness for both an individual and general people. The media can report news about governmental activities taken place in the community and present opinions on editorials, articles, and critics to inform the local of government projects and how they develop the local community. At the same time, the media can also present the local people's opinions to the governmental institutes, so that the institutes can be acknowledged of the local's opinions (Khorpholklang, 2015). Regarding this study, the data were collected through in-depth interviews with mass media professionals who have at least 10 years of experience. This research has a purpose to study the local mass media's attitudes toward an environmental situation in the east of Thailand.

\section{Research Methodology}

This research is a qualitative study with in-depth interviews with mass media professionals through the purposive sampling of 2 mass media who have more experience than 10 years living in the East of Thailand. They include 1) Napat Khunnaklad - Vice President of Association of Journalists in Chonburi, and 2) Amporn Saengkaew -

Received: 2019-11-06, Revised: 2019-12-06, Accepted: 2019-12-31 
President of Association of Journalists in Pattaya.

\section{Results and Discussion}

In-depth interviews on local media's attitude towards the environmental situation in the east of Thailand are described in figure 1.

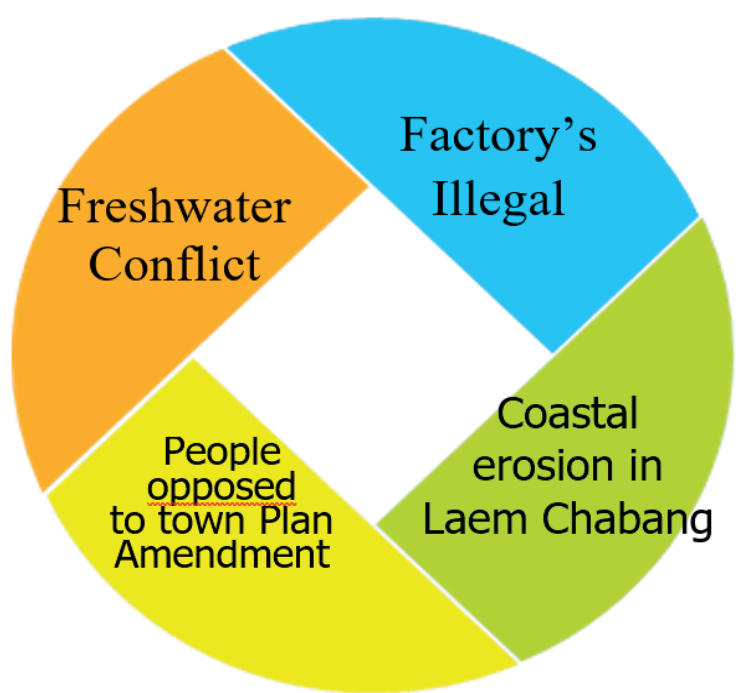

figure 1. Local Mass Media's Attitudes toward Environmental Situations in the East

Figure 1 revealed the local mass media's attitudes towards the environmental situations in East Thailand with4 issues as follows:

\section{Factories Illegally Disposed of Chemical Waste in Other People's Properties}

The study found that illegal waste disposal was distributed into waste disposal of other people's properties and waste disposal into canals.

Waste disposal in other people's properties. Regarding illegal chemical waste disposal on people's properties, research shows that workers from factories in the Eastern area illegally disposed of garbage including industrial waste on people's properties or lands and public lands; therefore, the people living about the neighborhood were afflicted by the smell of the garbage and chemical waste. Some of the landlords had known that their properties were filled with all these wastes, but they could do nothing to protect their properties because they never knew when their properties were filled with all these trashes and who did that. It stated that:

"People illegally dumped trash on other people's properties or public lands and wastelands. They came in convoys of trucks. They were just reckless. Some of the landlords did not know about the dumping of waste on their lands, but some knew. Still, they could do nothing because they did not know who did it. The smell of the waste was unbearable, even when passing. Not to mention those who live nearby the areas. They are living in a miserable situation." (Napat Khunnaklad)

Some of the media mentioned that people living in the areas had to smell the chemicals and breathed polluted air for long which affected their lives. Accordingly, all these people proposed this problem to the related governmental institutes and they founded a community called, "The Network of Friends in the East". The network comprised scholars, representatives from NGOs, and people who were affected by the smell of waste. They filed complaints to the governmental institutes, but nothing happened. Later, they tried to find their own solutions.

Besides trash and garbage, industrial waste was also illegally dumped. This waste was harmful to humans and animals. All the waste must be undergone proper sanitary landfills. If not, it would affect the human respiratory system.

"This type of news was gradually presented by the media in order to inform the people about how chemical waste would afflict people's respiratory system. The villagers all realized about this fact; however, they had no choice but tolerate." (Amporn Saengkaew)

Waste disposals into canals. Regarding the disposal of chemical waste into canals, the study revealed that the media in the East has been presented in news reports, scoops, and editorials. It was written to inform people of the situations and at the same time warn the factories that they should treat all waste first before dumping it since it can be dangerous for water animals and people. Some media reported that they were invited by particular factories to inspect wastewater management. They learned about the modern and effective process of wastewater management. These factories wanted to show that they never cause any pollution to the nearby communities. Some local media in East Thailand reported that there was little attention to waste disposal. There was 
no news investigation on which factories disposed of waste into the canals, how the polluted water affected the environment and water animals, and how people would be afflicted if they consume those water animals.

\section{Coastal Erosion in Laem Chabang area}

The study revealed that coastal erosion in Laem Chabang was distributed into Land loss and Potential catch loss.

Land loss. The study revealed that coastal erosion damaged Laem Chabang area including the people and business operators around the area. The sea had encroached more than 50 Rai $(80,000 \mathrm{sqm})$ of land. If the government institutes did not try to find solutions, the erosion would go on. This erosion problem had emerged in many coastal provinces, for example, Bang Khun Thian District, Phetchaburi, Prachuap Khiri Khan, and southern provinces. Coastal erosion in Laem Chanbang area is a vital problem because the land that has been encroached upon is more than 50 Rai. Actually, it is believed that the erosion might have destroyed more than 50 Rai of land; however, no one has done a close inspection. Coastal erosion in the East could be found not only in Laem Chabang area but also in other eastern provinces, for instance, Chantaburi, Trat, Rayong, Chonburi. In Chonburi, the areas encroached by the sea included Bang Lamung District, Muang District, and Sattahip District. The erosion can be worsened by the sediments containing metal stains. This can be found in Sattahip and Bangsaen. It is one of the biggest problems of coastal provinces.

Potential catch loss. The villagers said that it was much difficult to catch sea animals. In the past, they did not have to go far from the shores. They left at 3 or 4 o'clock in the morning, then they could be back just before noon with plenty of fish. These days, they have to go further and spend more time and come back with fewer catches. After interviewing the residents of Laem Chabang, the local media learned that the people were worried that the government's installation of breakwaters would affect their lives because the sea current would be changed. And this would lead to the collection of the sediments that would replace the beautiful beaches. Therefore, the local people wanted the government to review the plan to install the breakwaters since it would affect their lives.
The governmental institutes should study the effects and explain to local people whether this affects their lives or not. Without such an explanation, there would be problems.

\section{People's Opposition of the Town Plan Amendment}

The study showed that people's opposition of the town plan amendment was distributed into The opposition of government's town plan development and the opposition of the town plan development benefitting the investors,

The opposition of the government's town plan development. The study found that the governmental institutes planned to arrange new town plans in the East, so they studied the town plans and projected to amend the town plans to improve town management. They had studied both positive and negative facets before the policies were launched. The amendment is necessary and profitable in the future. The government has cooperated with the local administrative organizations.

The opposition of the town plan development benefitting the investors. When the local media presented news on people's opposition against town plan amendments, the local people then realized that the government wanted to do so; hence, some of the residents ran for the movement against the amendment by saying that they did not agree with what the governments would do because the local people would not get the full benefits of the projects, only some investors would. Some of the landlords and owners of properties felt that they would be affected from the amendments, so they filed complaints to the government to solve the problems. However, solutions to the problems might affect their properties, lands, and houses. They are worried, so they asked the governmental institutes to study the impacts thoroughly. If the government wants to compensate those who are affected, it should be clear on how to do that for them. The local people thought that they lost some advantages. They held discussion forums against the amendments, and media reported the issues, concerns, and suggestions rose on the forums. The media listen to both governmental institutes and scholars who were against the town plan amendments. The scholars agreed with town plan amendments; however, when the details were studied, these scholars stated 
that the amendments would only benefit the capitalists. The rich gain more advantages than the locals.

\section{Freshwater conflict}

The study found that the freshwater conflict was distributed into Freshwater conflict between agriculture and industrial sectors, and the invasion of the industrial sector into the agricultural area.

The freshwater conflict between agriculture and industrial and industrial sectors. The study revealed that there was a freshwater conflict between agricultural and industrial sectors. With the high growth of the industrial sector, water conflict became unavoidable. Regarding the topic of freshwater conflict between the agricultural and industrial sectors, the study found that the industrial sector in the East was growing since there are factories moved from the central area after a disastrous flood in 2011. The local agriculturists in the East needed water for their vegetables, plants, and fruit orchards, while the factories also needed a huge amount of water for their plants. As a consequence, the freshwater conflict occurred. The local media were reporting this conflict and saying that the governmental institutes needed to settle the conflict and find water to serve the need of both agricultural and industrial sectors. It reads:

Some mass media said that many coastal provinces in the East had plenty of seawater, but the agriculturists needed fresh water for cultivation. Thus, the government has to provide a sufficient amount of quality freshwater for its people. Freshwater becomes very difficult to find and the government has to develop freshwater resources to serve the need of both industrial and agricultural sectors or else the freshwater conflict can become severe. Some media said that in the past 2-3 years, many eastern provinces encountered drought that led to the insufficiency of freshwater for the agricultural sector. The local media reported this news to the public and asked the government to solve this problem of drought and provide enough water for the people in the East. The reservoirs in Rayong and Chonburi almost dried up. This might be a server in the future.

The invasion of the industrial sector into the agricultural area. The invasion of industrial estates to the agricultural areas. The study found that after disastrous floods in the northern and central areas in 2011, industrial estates in those areas moved their bases to the East. These estates bought many plots of lands in the East from the local. As a consequence, many people thought that the industry was invading agriculture. The capitalists bought thousands of plots of land. This affected the lives of the locals because many of them make their living from agriculture. Apart from the invasion of industry, local media also stated that besides the loss of lands from the local agricultural sector, industrial waste was another big problem because all the waste was dumped in many areas and most of the waste contained toxic chemicals that harmed plants, vegetables, and fruit. Plants die or produce fewer harvests.

\section{Results and Discussion}

The study on "The Local Mass Media's Attitudes towards the Environmental Situations in the East" can be explained as follows: the local mass media reported news of illegal waste and chemicals toxic disposal on people's properties and into canals. The local residents who live nearby the areas were afflicted by smells of trash and chemicals. The local filed complaints to the related governmental offices, but the government offices could not solve the problem. The residents had to breathe in these toxic chemicals every day. The media reported this topic and urged the people to be aware of the negative impacts they may get from this toxic chemical. Ruangchai and Inmuong (2014) stated about the negative effects of toxic chemicals as when inhaling or breathing in toxic chemicals, an individual may get dizziness, nausea, and vomit. In addition, there are findings from Pongwiriyakarn and Siwadechathep's (2016) reporting that food processing manufacturers in Ranong had not legally filed permission to transfer industrial wastes from their factories. Also, some of the factories had never filed permissions to transfer toxic wastes to other people's properties or land. This directly and dangerously affects people's life and health.

The second environmental problem in the East was coastal erosion in Laem Chabang area. The study revealed that land loss has caused 50 rai of land loss and potential catch loss. The residents and fishermen there were badly affected. In the past, they did not have to go far into the sea to catch sea animals, but after the coastal erosion emerged, these people had to go further to catch. Coastal 
erosions happened in many coastal provinces. This research is in accordance with Jitraporn's (2006) study on coastal erosion and human rights in Chonburi, Rayong, Chantaburi, and Trat. Her study revealed that coastal areas on the Thai Gulf side had been severely eroded especially during monsoonal seasons. The government had built up groins to protect the shorelines. At the same time, this study raised that the local residents had been worried that it would be far more difficult to catch sea animals.

The third problem was the people's opposition to the town plan amendment projected by the government. The study found that the government had planned to amend the town plan as it became necessary because they wanted to keep the town neat and organized; however, the residents found that the town plan amendment would benefit the investors rather than the local. Some real estate operators and residents were worried about the amendment. The local media reported and expressed their opinions about this amendment to urge the government to study the positive and negative impacts of the project and reported the study result to the local residents. With a thorough study and understanding, the chances of further problems would be limited. The study is in accordance with the news report from Matichon (newspaper) saying that more than $50 \%$ of the local residents worked against the town plan amendment. The town plan expropriated the lands from the locals, thus, many families had to move out. Even though the locals were compensated, the money they got was so little compared to what they lost (Matichon, 2019).

The last is the conflict between agricultural and industrial sectors. Most people in eastern provinces were agriculturists who needed fresh water for cultivation and in the East, the factories which had been moved from other central provinces due to the devastating floods in 2011, such as Bangkok and Ayuttaya, needed fresh water to supply their plants as well. Consequently, freshwater was not sufficient for both agriculture and industry. The local residents felt that these factories seized the water supplies from the agricultural sector. Moreover, some capitalists bought up plots of lands in the East and turned the orchards into industrial estates. The locals felt that the factories invaded agriculture.

The local media's news presentation about environmental problems in the eastern part of Thailand was considered as a role of informing the public, and at the same time, the media in the East were also educating the people in the area about the effects of toxic chemicals. Moreover, the media acted as a watchdog monitoring the goings-on in the society by reporting news about the illegal toxic disposals on other people's properties, public lands, and canals. This helped the local people to be aware of the effects of these disposals of industrial waste on their health.

This is in accordance with Thitiya Pleancheai's study (2011) stating that in the selection of news to be presented locally, the editor would set time and place for the particular news report for his/her own local. The selection of news was directed related to the local people's perceptions because this piece of news would lead the people to think of the impacts that would affect their lives. Pleancheai's study mentioned the media's role in warning the people about the effects that might emerge. Moreover, the study is in accordance with Somchinda's study (2017) on Mass Media Role of Siam news Local Newspaper (Chanthaburi) and Perception of the Receivers. The study revealed that local newspaper reported news involving the local ways of life so that the local newspaper's role benefited the people living in the area directly. News selection solely depended on the editor.

In addition, the study also gets along with Pruworini, Kuswarno, Hadisiwi, and Rakhmat's study titled (2016) "The Naturalization Policy in Online News Media". This study indicated that the media would craft and rearrange the piece of news before publicizing it. The publication of the news would arouse the public interest in the issue reported. This is in accordance with the agenda-setting theory. This conforms to Songyot Buaphuean's study (2017) "Mass Media and Ideology Dissemination against Democracy in Thailand" stating that mass media was a social institute that produced and publicized news to the public. News presentation also informed people of the goings-on at the very moment where people could learn about significant events or issues at that moment by inspecting the amount, frequency, and length of the news report. As mass media in the East present message to people, it made them perceive and realized the problems so that they tried to solve those problems. 


\section{Conclusion}

Mass media have the power to spread the news and make an impact on people who read them. This research discussed four issues of media concern. First, the issue of illegal waste and chemicals toxic disposal on people's properties and into canals. The local residents who live nearby the areas were afflicted by the smells of the trash and chemicals. They filed complaints to the related governmental offices but did not get the appropriate solutions. The media reported this topic and urged the people to be aware of the negative impacts they may get from this toxic chemical.

The second issue was coastal erosion in Laem Chabang area. The study revealed that land loss has caused 50 rai of land loss and potential catch loss where the residents and fishermen were badly affected. In the past, they did not have to go far into the sea to catch sea animals, but after the coastal erosion emerged, they had to go further to catch. The local mass media reported this issue so that people and government alike could be aware of.

The third issue was the people's opposition to the town plan amendment projected by the government. The government had planned to amend the town plan to keep the town neat and organized, but the residents found that the plan would only benefit the investors. Some real estate operators and residents were worried about the amendment. The local media reported and expressed their opinions about this amendment to urge the government to study the positive and negative impacts of the project and reported the study result to the local residents

The last issue was the conflict between agricultural and industrial sectors. Agriculturists in eastern provinces of Thailand needed fresh water for their cultivation, while the factories that had been moved from other central provinces needed fresh water to supply their plants as well. Consequently, freshwater was not sufficient for both agriculture and industry. The local residents felt that these factories seized the water supplies from the agricultural sector. Moreover, some capitalists bought up plots of lands in the East and turned the orchards into industrial estates. The local felt that the factories invaded the agriculture

The selection of news was directed related to the local people's perceptions because this piece of news would lead the people to think of the impacts that would affect their lives. The local newspaper reported news involving the local ways of life so that the local newspaper's role benefited the people living in the area directly.

The local media's news presentation about environmental problems in the eastern part of Thailand was considered as a role of informing and educating the public. Moreover, the media could also act as a watchdog monitoring the goings-on in society and help the local people to be aware of everything happened in their environment.

\section{Acknowledgment}

This research article is a part of a research study on "Roles of Mass Media and Democracy Promotion of people in the East of Thailand". The study was financially supported by the National Research Council of Thailand in the fiscal year 2016 under the research project code of 222849 .

\section{References}

Buaphuean, S. (2017). Mass Media and Ideology Dissemination against Democracy in Thailand. MIMBAR Jornal Sosial dan Pembangunan.Volume 33. No.1.(158165)

Buaphuean, S.(2006). Roles of Mass Media and Democracy Promotion of people In the East of Thailand. Communication Arts Reviews Journal.Vo.20, Special (103-117).

Jitraporn, F. (2006). The study of coastal erosion and human rights in Chonburi, Rayong, Chantaburi, and Trat.Marine Science, (Faculty of Fisheries, Kasetsart University)

Khorpholklang, N. (2015). Capabilities Development of Local Media for Health Communication in Northeastern Rural. Suranaree. Journal of Social Science.Vol. 9 No.2; December 2015 (61-77).

Matichon. (2019). Matichon Online. https:// www.matichonweekly.com/ (Retrieved December, 23, 2019).

Pongwiriyakarn, S., and Chakkrit Siwadechathep, C. (2016). Industrial Waste Management of Frozen Seafood Processing Plant in Ranong Province. Journal of Safety and Health. Volume 32. No.9. April - June.

Pruworini, D., Kuswarno, E., Hadisiwi, P.,\& Rakhmat, A.(2016). The Naturalization Policy in Online News Media. MIMBAR Jornal Sosial dan Pembangunan. Volume 
32. No.2.

Ruangchai, S., and Inmuong, Y. (2014).

Tobacco Farmers' Health Impact of Pesticide use in Lamhuay Lua Sub-District, Somdej District, Kalasin Province. www. semanticscholar.org.
Somchinda, W. (2017). Mass Media Role of Siamnews Local Newspaper (Chanthaburi) and Perception of the Receivers. Journal of Siam Communication Arts Review, Vol.16. No.2. 